Article

\title{
Aliphatic Anion Exchange Ionomers with Long Spacers and No Ether Links by Ziegler-Natta Polymerization: Properties and Alkaline Stability
}

\author{
Raul Andres Becerra-Arciniegas ${ }^{1,2}$ *, Riccardo Narducci ${ }^{1, * \mathbb{D}}$, Gianfranco Ercolani ${ }^{3} \mathbb{D}$, Luca Pasquini ${ }^{2}$ (D), \\ Philippe Knauth ${ }^{2}$ (D) and Maria Luisa Di Vona ${ }^{1}$ (D)
}

Citation: Becerra-Arciniegas, R.A.; Narducci, R.; Ercolani, G.; Pasquini,

L.; Knauth, P.; Di Vona, M.L.

Aliphatic Anion Exchange Ionomers with Long Spacers and No Ether

Links by Ziegler-Natta

Polymerization: Properties and

Alkaline Stability. Molecules 2022, 27, 395. https://doi.org/10.3390/

molecules27020395

Academic Editors: Giuseppe Cirillo and Igor Djerdj

Received: 5 December 2021

Accepted: 6 January 2022

Published: 8 January 2022

Publisher's Note: MDPI stays neutral with regard to jurisdictional claims in published maps and institutional affiliations.

Copyright: (C) 2022 by the authors. Licensee MDPI, Basel, Switzerland. This article is an open access article distributed under the terms and conditions of the Creative Commons Attribution (CC BY) license (https:// creativecommons.org/licenses/by/ $4.0 /)$
1 Department of Industrial Engineering and International Laboratory "Ionomer Materials for Energy", University of Rome Tor Vergata, Via del Politecnico 1, 00133 Roma, Italy; divona@uniroma2.it

2 Aix-Marseille Univ, CNRS, MADIREL (UMR 7246) and International Laboratory "Ionomer Materials for Energy", Campus St Jérôme, 13013 Marseille, France; luca.pasquini@univ-amu.fr (L.P.); philippe.knauth@univ-amu.fr (P.K.)

3 Department of Chemical Sciences and Technologies, University of Rome Tor Vergata, Via della Ricerca Scientifica, 00133 Roma, Italy; ercolani@uniroma2.it

* Correspondence: raul-andres.becerra-arciniegas@etu.univ-amu.fr (R.A.B.-A.); riccardo.narducci@uniroma2.it (R.N.)

Abstract: In this work we report the synthesis of poly(vinylbenzylchloride-co-hexene) copolymer grafted with $\mathrm{N}, \mathrm{N}$-dimethylhexylammonium groups to study the effect of an aliphatic backbone without ether linkage on the ionomer properties. The copolymerization was achieved by the ZieglerNatta method, employing the complex $\mathrm{ZrCl}_{4}(\mathrm{THF})_{2}$ as a catalyst. A certain degree of crosslinking with $\mathrm{N}, \mathrm{N}, \mathrm{N}^{\prime}, \mathrm{N}^{\prime}$-tetramethylethylenediamine (TEMED) was introduced with the aim of avoiding excessive swelling in water. The resulting anion exchange polymers were characterized by ${ }^{1} \mathrm{H}-\mathrm{NMR}$ FTIR, TGA, and ion exchange capacity (IEC) measurements. The ionomers showed good alkaline stability; after $72 \mathrm{~h}$ of treatment in $2 \mathrm{M} \mathrm{KOH}$ at $80^{\circ} \mathrm{C}$ the remaining IEC of $76 \%$ confirms that ionomers without ether bonds are less sensitive to a $\mathrm{S}_{\mathrm{N}} 2$ attack and suggests the possibility of their use as a binder in a fuel cell electrode formulation. The ionomers were also blended with polyvinyl alcohol (PVA) and crosslinked with glutaraldehyde. The water uptake of the blend membranes was around $110 \%$ at $25{ }^{\circ} \mathrm{C}$. The ionic conductivity at $25^{\circ} \mathrm{C}$ in the $\mathrm{OH}^{-}$form was $29.5 \mathrm{mS} / \mathrm{cm}$.

Keywords: poly(vinylbenzylchloride-co-hexene); PVA blend membranes; alkaline stability; copolymer; ionic conductivity

\section{Introduction}

Anion exchange membranes (AEMs) are ion conducting materials used in several applications like anion exchange membrane fuel cells (AEMFCs) [1-4], water electrolysers [5], water treatments, and redox flow batteries [6,7]. AEMFCs are promising to decrease the cost of fuel cell devices because less expensive and more abundant electrocatalytic materials, such as nickel, iron, silver, or carbon nanotubes, can catalyze the oxygen reduction reaction (ORR) in basic conditions [8].

In redox flow batteries, anion exchange membranes attain low ion permeability and high selectivity, which are critical conditions for the success of the device [9]. However, the insufficient stability of currently existing hydroxide conducting ionomers in alkaline media is an important challenge for this field [3,10]. Regarding the stability of cationic groups, ammonium presents several degradation mechanisms; the second order nucleophilic substitution $\mathrm{S}_{\mathrm{N}} 2$ is difficult to prevent and depends on the strength and concentration of the nucleophile and ammonium moiety [11]. The Hoffman elimination (E2) can be avoided using ammonium groups without $\beta$-hydrogens or structures where it is impossible to reach an anti-periplanar conformation; the ylide formation is difficult to inhibit [12-14]. The 
backbone is responsible for the mechanical properties and among many other commercial polymers, poly(2,6-dimethyl-1,4-phenylene oxide) (PPO) is stable in alkaline conditions and is easy to functionalize [15-17]. However, the functionalization can alter the charge distribution and destabilize the ether linkage which becomes sensitive to the attack of $\mathrm{OH}^{-}$; consequently, the conductivity is lowered and the polymer becomes fragile [11]. Various strategies have been explored to decrease the degradation [18] including a change of the polymer backbone [19,20], the introduction of long side chains, [21-24], and the delocalization of the positive charge $[13,25]$. Similarly, the use of composites with stable inorganic materials in alkaline environments such as hydrotalcites have shown an improvement in mechanical properties [26-29].

Recently, important advances have been made on AEMs based on aromatic polymers without ether bonds. For instance, Lee et al. [30] introduced a new synthetic design to obtain bromoalkyl-tethered poly(biphenyl alkylene)s by acid-catalyzed Friedel-Crafts polycondensation. AEMs were obtained with good chemical stability in alkaline media. In 2018 Pham et al. [31] improved thermal stability and hydroxide ion conductivity with the introduction of $\mathrm{N}$-spirocyclic quaternary ammonium cations; the thermal stability was attributed to the high aromaticity and rigidity of the cationic copolymers. Other types of AEMs with similar polymeric matrix and architectures have been explored obtaining exceptional chemical stability and hydroxide ion conductivity [32-34].

In this study we focus on the backbone, in particular on the study of how the absence of ether bonds in the polymer matrix improves the chemical stability of anion exchange ionomers, synthesizing the copolymer poly( $\mathrm{VBCl}$-co-hexene). We chose the Ziegler-Natta polymerization ( $\mathrm{ZNp}$ ) because this technique of polymerization is the most suitable for the synthesis of poly alpha-olefins [35] and co-polymerization of alpha-olefins with styrenic monomers [36]. It has also been employed for the homopolymerization of styrenic monomers [37]. The ZNp allows the control of the stereospecificity, depending on the nature of the employed catalyst [38,39]. This chemical reaction is one of the most important at an industrial level for the synthesis of plastic materials and derivatives, such as high-density polyethylene (HDPE), linear low-density polyethylene (LLDPE), syndiotactic and isotactic polypropylene [40], among others. An eventual production of ionomers though this synthetic method would be inexpensive, because the $\mathrm{ZNp}$ has already been developed at large-scale. Zhu et al. [41] in 2019 reported for the first time the use of classical $\mathrm{ZNp}$ for the synthesis of AEMs. They employed $\mathrm{TiCl}_{4}$ activated with methylaluminoxane (MAO) as a catalyst. The authors found a remarkable stability with just $15 \%$ to $20 \%$ of degradation after $1000 \mathrm{~h}$ in $1 \mathrm{M} \mathrm{NaOH}$ at $80^{\circ} \mathrm{C}$. In 2019, a great advance in AEMs was achieved with the use of poly(norbornene), a polymer with an aliphatic backbone synthesized by different polymerization techniques such as $\mathrm{Pd}(\mathrm{II})$-catalyzed addition polymerization [42] or ring-opening metathesis polymerization [43]. Membranes based on poly(norbornene) were highly resistant to the degradation. This progress make the use of aliphatic backbones in AEMs attractive.

In this work, we employ the $\mathrm{ZrCl}_{4}$ (THF) $)_{2}$ complex as a catalyst. This complex was tested for the first time in 2003 by Proto et al. [44], for the propylene, ethylene, and styrene homopolymerizations. They obtained high molecular weights for ethylene and propylene, as well as a high degree of iso- and syndio- tacticity. The good catalytic performance of this complex was associated with the presence of neutral ligands (electron donors) such as THF or diethyl ether.

We aimed in this work: (i) to synthesize the new copolymer poly(VBCl-co-hexene) with no ether linkage looking for an increased stability in strong alkaline conditions, (ii) to obtain a high ionic conductivity because of the introduction of long spacer chains into the backbone and with the introduction of ammonium groups on long side chains, (iii) to obtain a blend membrane of poly(VBCl-co-hexene) and polyvinyl alcohol (PVA), presenting a plastic behavior similar to $\mathrm{Nafion}^{\circledR}$ due to the use of a flexible aliphatic backbone in both polymers. 


\section{Results and Discussion}

\subsection{Synthesis and Characterization of the Copolymer Poly(VBCl-co-hexene)}

The reaction carried out for the synthesis of the copolymer poly(VBCl-co-hexene) is shown in Figure 1.

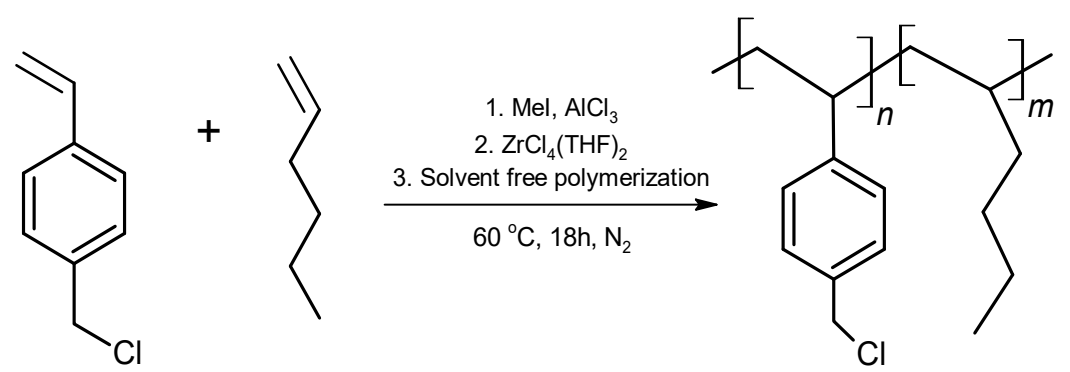

Figure 1. Ziegler-Natta polymerization for the synthesis of poly(VBCl-co-hexene).

One of the most accepted mechanisms for the Ziegler-Natta polymerization reaction was established by Cossee in 1964. The activation of the catalyst is reported in Figure 2a [45].
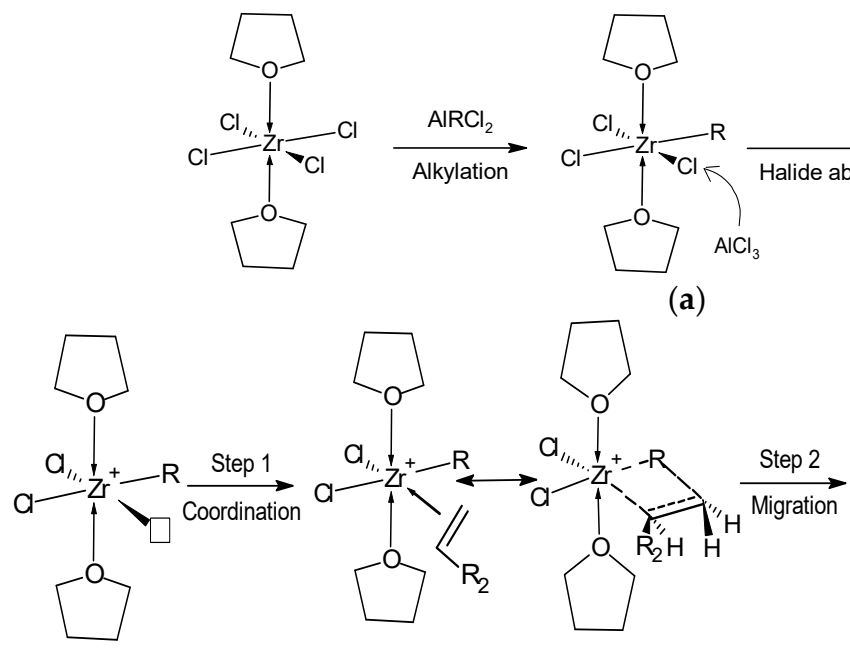

(b)

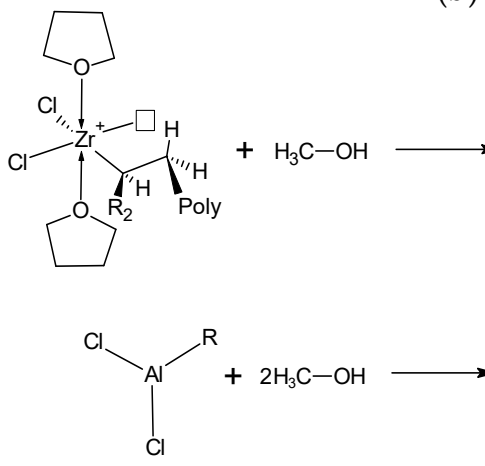

(c)
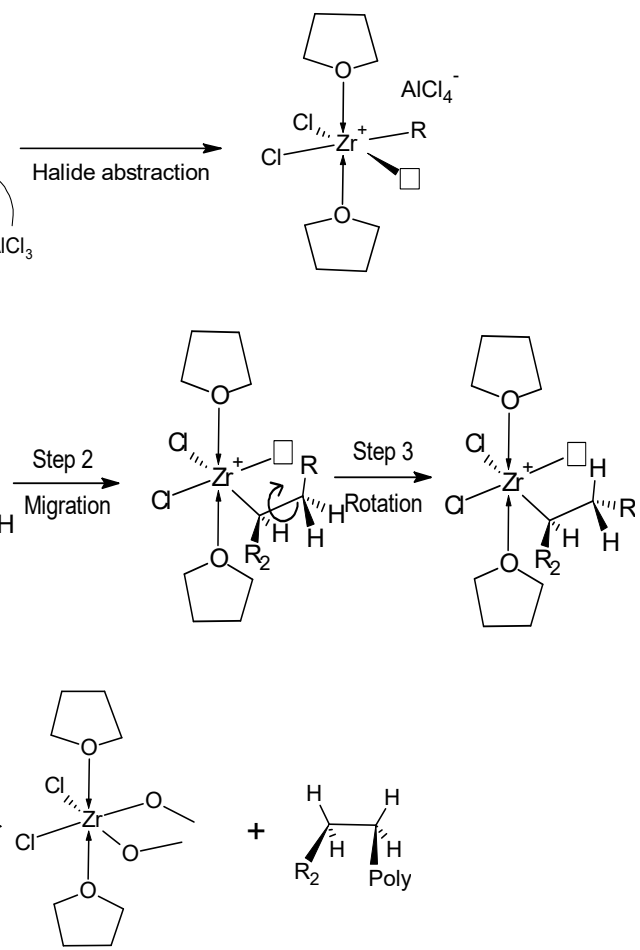<smiles>[R]N(OC)OC</smiles>

Figure 2. Ziegler-Natta polymerization: (a) Activation of the catalyst. The arrows represent the coordination bonds and the square, a vacant position; (b) Propagation reaction. $\mathrm{R}_{2}$ represents the pendent group of the monomer, it can be aliphatic or aromatic; (c) Termination reaction.

When the monomers enter into contact with the activated catalyst, mainly three processes take place (Figure $2 b$ ). (i) The first step is the coordination of the monomer to the transition metal. (ii) The second step involves the "migratory insertion" of the alkyl group (R) from the $\mathrm{Zr}$ atom to a carbon atom of the olefin. This process takes place by a concerted reaction; at the same time new active sites are formed. (iii) The last step is the 
rotation about the $\mathrm{C}_{\alpha}-\mathrm{C}_{\beta}$ single bond of the extended alkyl group. This movement of $\mathrm{R}$ allows another monomer to coordinate to zirconium.

The growth of the polymer chain (propagation reaction) is carried out by repeating the three steps until a termination reaction takes place (organometallic catalytic cycle). The termination reactions can occur through different processes such as: (a) $\beta$-elimination from the polymer chain, forming metal hydride; (b) $\beta$-elimination with hydrogen transfer to the monomer; (c) hydrogenation. In order to deactivate the catalyst, we employed a solution of $2 \%$ of $\mathrm{HCl}$ in methanol. The possible products obtained are shown in Figure 2c. The alcohol may react with a Ziegler-Natta cocatalyst such as $\mathrm{AlR}(\mathrm{Cl})_{2}$ to produce aluminum alkoxy/hydroxy compounds and an alkane. The aluminum alkoxy/hydroxy compounds cannot function as an effective cocatalyst and thus the polymerization catalyst is deactivated [46].

\section{2. ${ }^{1} \mathrm{H}-\mathrm{NMR}$ Analysis}

Copolymers were synthesized employing different molar ratios of monomers hexene:VBCl 4:1 and 2:1. The ${ }^{1} \mathrm{H}-\mathrm{NMR}$ spectra of the samples are shown in Figure $3 \mathrm{a}, \mathrm{b}$. Figure 3 a corresponds to the copolymer synthesized with a monomer ratio 4:1. The signal (a) between 6.5 and $7.3 \mathrm{ppm}$ is attributed to aromatic hydrogens $(4.0,4 \mathrm{H})$ of the $\mathrm{VBCl}$ portion. The signal (i) around $0.9 \mathrm{ppm}(3 \mathrm{H})$ corresponds to the methyl group coming from the hexene monomer; we attributed to it an integral of 3 . The peak (b) at $4.6 \mathrm{ppm}$ is related to the chloromethylated moieties $(0.4,2 \mathrm{H})$, while the signal around $3.8 \mathrm{ppm}(0.1,2 \mathrm{H})$ is characteristic of the $\mathrm{Ph}-\mathrm{CH}_{2}-\mathrm{Ph}$ portion due to a side Friedel-Crafts reaction between the chloromethylated moieties and aromatic groups [47]. The integral of aromatic hydrogens present in $\mathrm{VBCl}$ is generally used to estimate the ratio between the monomers [48], in our case, the aromatic hydrogens overlap with the signal of the solvent $\left(\mathrm{CDCl}_{3}\right)$ which makes an accurate assessment impossible. Considering the initial ratio of hexene and $\mathrm{VBCl}(4: 1), 3 \mathrm{H}$ (i) of the $\mathrm{CH}_{3}$ group correspond to $0.5 \mathrm{H}$ of benzylic moieties $\left(\mathrm{b}+\mathrm{PhCH}_{2} \mathrm{Ph}\right)$, in accordance with the spectrum reported in Figure 3a. Therefore, $n=1$ and $m=4$. The theoretical degree of functionalization (DF) should be 0.20 , due to the presence of the Friedel-Crafts reaction the effective DF is 0.16 .

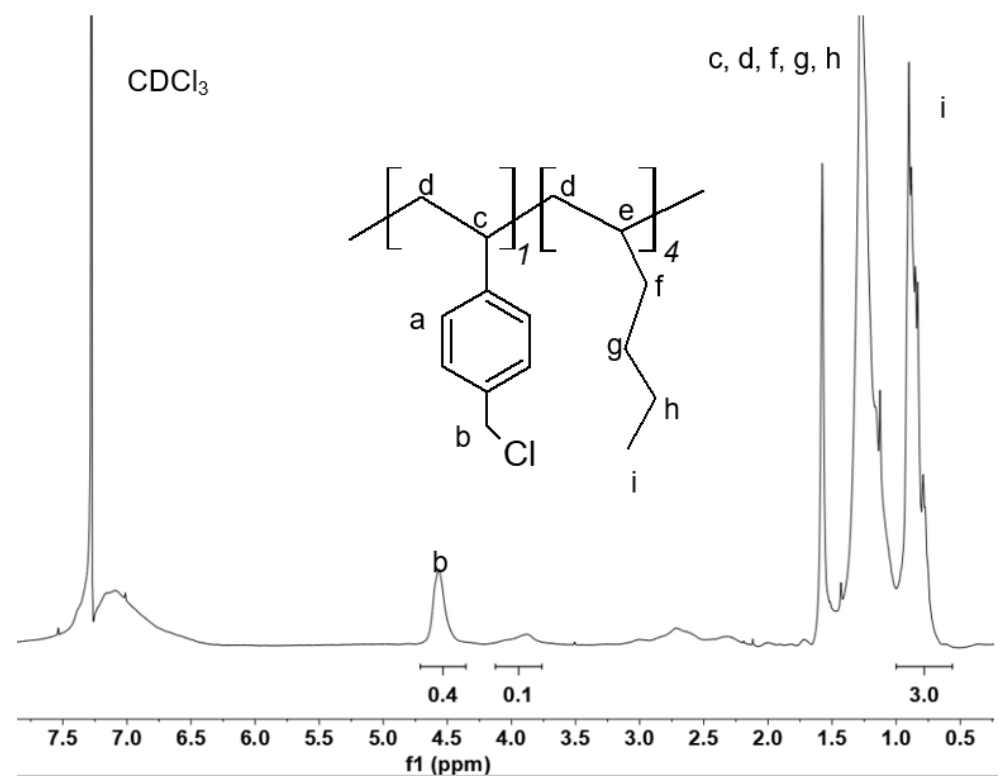

(a)

Figure 3. Cont. 


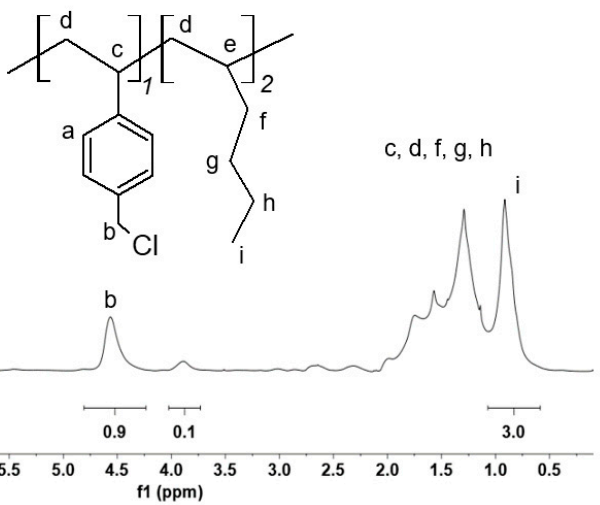

(b)

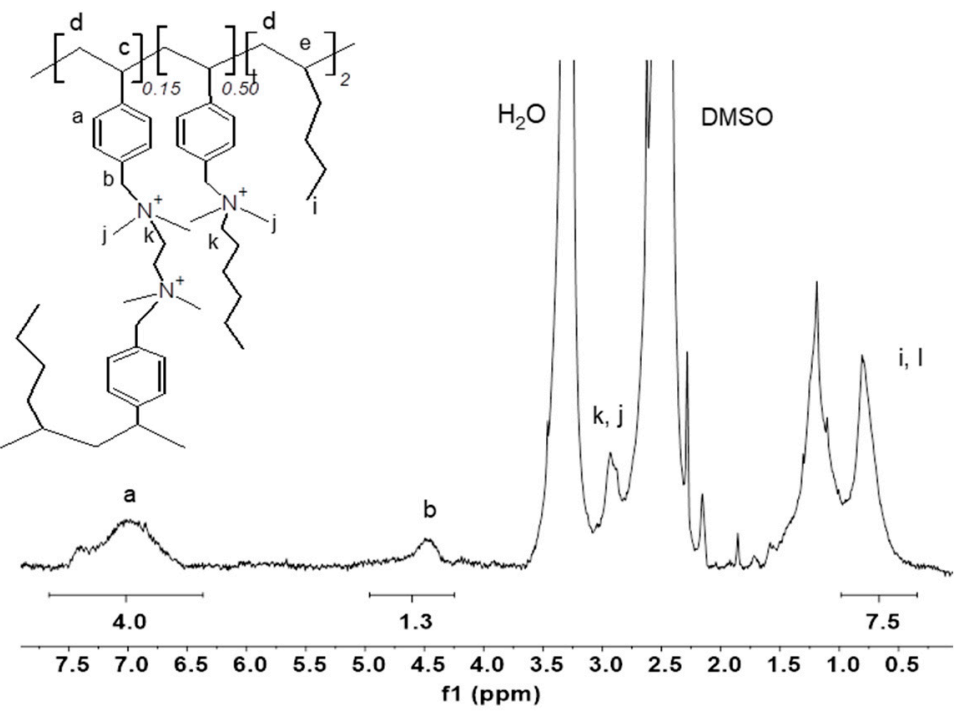

(c)

Figure 3. ${ }^{1} \mathrm{H}-\mathrm{NMR}$ spectra of: (a) Copolymer poly(VBCl-co-hexene) synthesized with a ratio hexene: $\mathrm{VBCl} 4: 1$ in $\mathrm{CDCl}_{3}$; (b) Copolymer poly(VBCl-co-hexene) synthesized with a ratio hexene: $\mathrm{VBCl}$ 2:1 in $\mathrm{CDCl}_{3}$; (c) Aminated and crosslinked ionomer in $\mathrm{d}_{6}$-DMSO.

The Figure $3 b$ shows the ${ }^{1} \mathrm{H}-\mathrm{NMR}$ spectrum of the sample synthesized with a ratio hexene: $\mathrm{VBCl}$ 2:1. The spectrum shows similar signals to the product analysed above. The ratio of hexene: $\mathrm{VBCl}$ in the copolymer calculated with the ${ }^{1} \mathrm{H}-\mathrm{NMR}$ spectrum considering both the signal at 4.6 and $3.8 \mathrm{ppm}$, is exactly $2: 1$, therefore, $\mathrm{n}=1$ and $\mathrm{m}=2$. The theoretical $\mathrm{DF}$ is 0.33 , the experimental one is 0.3 .

\subsection{Catalytic Activity of $\mathrm{ZNp}$}

The polymerization activity, reported in Table 1 , is lower in comparison with catalytic systems described in the literature for different homopolymers such as poly(propylene) and poly(styrene) prepared with the same catalyst $[44,49,50]$. We attribute the different catalytic activity to the absence of solvent in the system (solvent free reaction); as the reaction progressed, the viscosity increased, limiting the monomer transport to the active centers of the catalyst. Furthermore, we employed a mixture of $\mathrm{AlCl}_{3}+\mathrm{MeI}$ as cocatalyst, which is probably less efficient than the MAO used in the reported works. FTIR analysis (see later) showed the presence of isotactic poly(1-hexene) segments, demonstrating the stereospecificity of $\mathrm{ZrCl}_{4}(\mathrm{THF})_{2}$ for the $\mathrm{ZNp}$, as was previously observed for the synthesis of aliphatic homopolymers. The good stereospecificity of the catalyst was attributed by Proto et al. to the presence of neutral Lewis bases bonded to the metal [44]. 
Table 1. Catalytic activity and number of branches $/ 1000 \mathrm{C}$ obtained for the synthesis of poly(VBClco-hexene) at $60^{\circ} \mathrm{C}$ for $18 \mathrm{~h}$.

\begin{tabular}{cccc}
\hline $\begin{array}{c}\text { Monomer Ratio: } \\
\text { Hexene:VBCl }\end{array}$ & Reaction Yield (\%) & $\begin{array}{c}\text { Polymerization } \\
\text { Activity (a) }\end{array}$ & $\begin{array}{c}\text { Number of } \\
\text { Branches/1000 C (b) }\end{array}$ \\
\hline $4: 1$ & 43 & 0.021 & 6.1 \\
\hline $2: 1$ & 77 & 0.049 & 4.7 \\
\hline
\end{tabular}

(a) The polymerization activity was calculated as: $\mathrm{g}$ polymer $/\left(\mathrm{mmol} \mathrm{Zr} \times \mathrm{h} \times\right.$ [total monomer]). ${ }^{\text {(b) }}$ Branching numbers per 1000 carbons were determined by ${ }^{1} \mathrm{H}$ NMR spectroscopy.

The numbers of branches per $1000 \mathrm{C}$ are shown in Table 1; they were calculated assuming that only the Friedel-Crafts reaction took place as the source of branching. This assumption is in good agreement with the results reported by Proto et al., which found that the $\mathrm{ZrCl}_{4}(\mathrm{THF})_{2} \mathrm{ZNp}$ catalyst generates mainly linear polymers [44,50].

The branching reaction between the polymeric chains by Friedel-Crafts is due to the presence of $\mathrm{AlCl}_{3}$ in the system as reported in Figure 4. The appearance of a signal at $3.9 \mathrm{ppm}$ (Figure $3 \mathrm{a}, \mathrm{b}$ ) confirms the presence of a crosslinked structure.
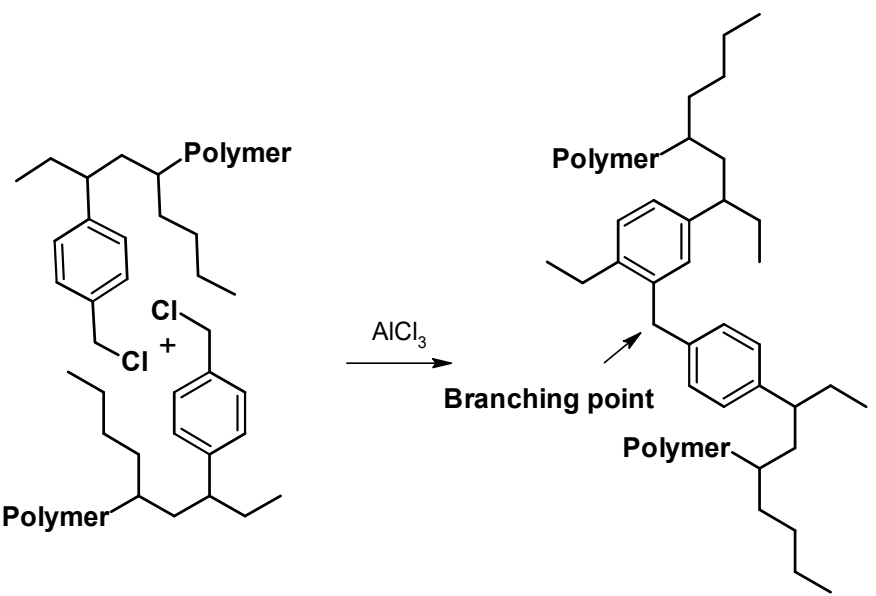

Figure 4. Illustration of the possible branching reaction.

The Friedel-Crafts reaction can be avoided by using different cocatalysts such as MAO. The degree of branching might be controlled by the amount of $\mathrm{VBCl}$ monomer, as observed in Table 1. The copolymers reported in this manuscript present quite a low degree of ramification in comparison with different polymers reported in the literature [51,52].

\subsection{Synthesis of the Ionomer Based on the Copolymer Poly(VBCl-co-hexene)}

For the synthesis of the ionomer, we chose the copolymer with $\mathrm{DF}=0.30$, initially exploring the quaternization with TMA and N,N-dimethylhexylamine. Unfortunately, the membrane made with TMA became soluble in water, while the one with $\mathrm{N}, \mathrm{N}$-dimethylhexylamine suffered of excessive swelling deteriorating its mechanical properties. These results are in agreement with literature reports that ionomers with aliphatic backbones present excessive swelling attributed to a low mass of monomers and a low interaction between the polymer chains. To avoid this issue, two main approaches were reported in the literature: (1) the decrease of the IEC below $1.6 \mathrm{meq} / \mathrm{g}[18,19,53,54]$ and (2) the formation of crosslinked polymers $[42,48,55-58]$. We chose to crosslink the copolymer $(\mathrm{DF}=0.3)$ with a diamine in order to increase the IEC and at the same time avoid excessive swelling. The ionomer was synthesized in two steps (Figure 5): (i) copolymer crosslinking with TEMED in defect; (ii) quaternization of unreacted $\mathrm{Ph}-\mathrm{CH}_{2}-\mathrm{Cl}$ with $\mathrm{N}, \mathrm{N}$-dimethylhexylamine. 


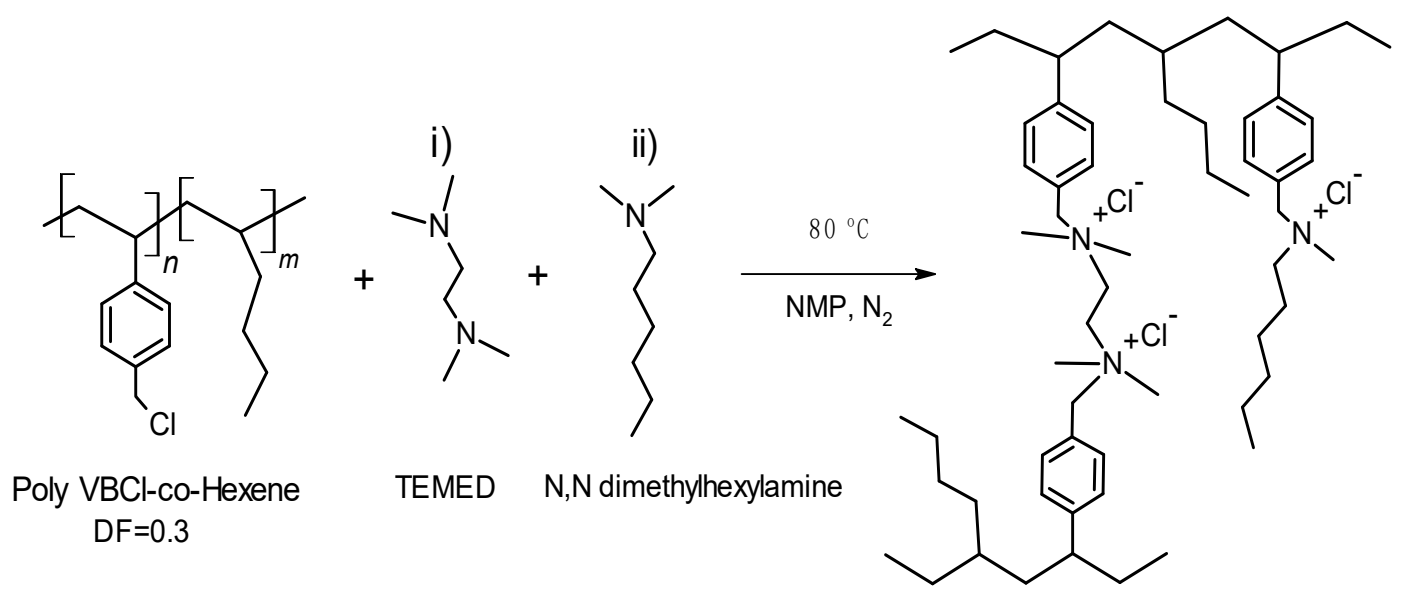

Figure 5. Pathways to synthesize the crosslinked ionomer based on poly(VBCl-co-hexene).

\section{5. ${ }^{1} \mathrm{H}-\mathrm{NMR}$ Analysis of the Crosslinked Ionomer}

The ${ }^{1} \mathrm{H}-\mathrm{NMR}$ spectrum of the crosslinked ionomer is shown in Figure $3 \mathrm{c}$. The aromatic hydrogens (a) were taken as a reference (four hydrogens) considering that their fraction in the polymer is $n=1$ and must remain unchanged after the quaternization reaction.

The presence of an additional $\mathrm{CH}_{3}$ from the $\mathrm{N}$, N-dimethylhexylamine (l) increases the value of the signal at $0.9 \mathrm{ppm}(\mathrm{i}+1)$ with respect to the sample reported in Figure $3 \mathrm{~b}$. Considering that $\mathrm{n}=1$ and $\mathrm{m}=2$, the peak (i) accounts for six hydrogens, the rest of hydrogens (1.5) can be assigned to (1) corresponding to $50 \%$ of the unit $\mathrm{m}$, that is the quaternized chloromethyl groups. The signal (b) integrates for hydrogens at the benzylic position of $\mathrm{Ph}-\mathrm{CH}_{2}-\mathrm{N}^{+}(65 \%)$. Accordingly, the crosslinking degree can be evaluated at around $15 \%$. The six hydrogens of the $\mathrm{CH}_{3}$ groups of the ammonium moiety $(\mathrm{j})$ and the two hydrogens in the alpha position of the alkyl side chain of the amines $(\mathrm{k})$ are observed around 2.9 and 2.7 ppm respectively [59]. These signals overlap slightly with DMSO.

The DAM can be evaluated at around 0.21 taking into account the 2 units of polyhexene and the unit of $\mathrm{VBCl}$.

\subsection{Infrared Spectra Analysis}

Figure 6 a shows the spectrum of the crosslinked ionomer. The signal at $642 \mathrm{~cm}^{-1}$ corresponds to the stretching of $\mathrm{C}-\mathrm{Cl}$ bond of benzyl chloride moieties that have not reacted during the quaternization reaction, as confirmed by the signal at $1263 \mathrm{~cm}^{-1}$ assigned to $\mathrm{CH}_{2} \mathrm{Cl}$ wagging vibrations [60]. The peaks at 1504, 1108, 1019 and $820 \mathrm{~cm}^{-1}$ correspond to the asymmetric $\mathrm{C}-\mathrm{N}$ stretching and bending of the quaternary ammonium groups [61]. The $\mathrm{CH}_{3}$ groups of the $\mathrm{R}^{\prime}$, $\mathrm{R}$-dimethyl ammonium moieties are expected to absorb in the region 3100-3020 $\mathrm{cm}^{-1}$; they overlap with the broad peak at $3330 \mathrm{~cm}^{-1}$, due to $\mathrm{OH}$ vibrations from water molecules in the membrane. At $1650 \mathrm{~cm}^{-1}$ is observed a second stretching vibration of water. There are absorption peaks at the wavenumbers of 2855 and $2924 \mathrm{~cm}^{-1}$ due to aromatic C-H stretching vibration absorption. At the wavenumber of $1130 \mathrm{~cm}^{-1}$ a shoulder is observed, corresponding to the aromatic ring in-plane deformation. There are four absorption peaks at the wavenumbers of $1605,1456,1419$ and $1306 \mathrm{~cm}^{-1}$, attributed to aromatic $C=C$ stretching vibration absorption $[62,63]$. The aliphatic backbone, poly(1-hexene) segments and aliphatic part of long side chain amine show two $\mathrm{C}-\mathrm{H}$ stretching vibration bands around $2940 \mathrm{~cm}^{-1}$, overlapping with the absorption peaks of the aromatic group; there are two other stretching bands around 1456 and $1376 \mathrm{~cm}^{-1}$ [64]. 

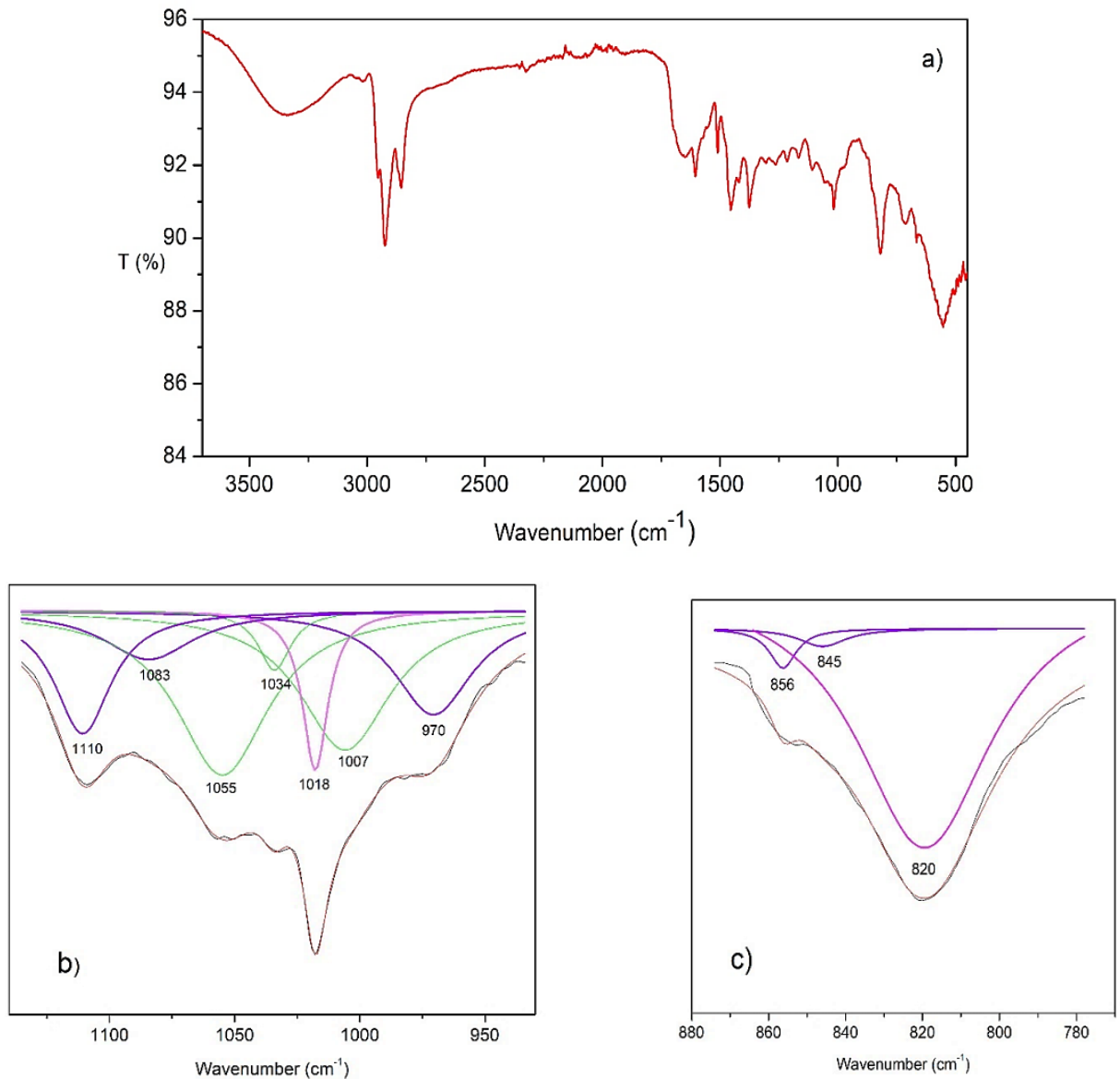

Figure 6. (a) FTIR spectrum of the crosslinked ionomer; (b) Zoom of the infrared spectrum between 930 and $1160 \mathrm{~cm}^{-1}$; (c) between 780 and $870 \mathrm{~cm}^{-1}$ and deconvolution of overlapped peaks. Signals of isotactic poly(1-hexene) segments (blue lines), signal of bending of quaternary ammonium groups (pink line), sum of peaks (red line), original signal (black line).

It is possible to observe overlapped signals around 1018 and $820 \mathrm{~cm}^{-1}$ (as mentioned above they are characteristic vibrations of quaternary ammonium groups). To know the contribution of each signal, we performed a deconvolution process, the results obtained are shown in Figure 6 b,c. Characteristic signals with small intensity originate from segments of isotactic poly(1-hexene); the wavenumbers at which typical vibration modes appear are: $1110,1083,970,856$ and $845 \mathrm{~cm}^{-1}$, they are shown in blue lines. The signals at 720, 1160 and $1214 \mathrm{~cm}^{-1}$ also correspond to isotactic poly(1-hexene). They have been observed in both homopolymers and copolymers [65-67]. The presence of isotacticity is in good agreement with the results reported by Proto et al. [44] for the synthesis of homopolymers employing the same catalyst used in this work.

\subsection{Stability Test of the Crosslinked Ionomer}

The degradation test of the crosslinked ionomer was made in $2 \mathrm{M} \mathrm{NaOH}$ at $80^{\circ} \mathrm{C}$. The IEC values of the ionomer (powder form) before and after degradation were obtained by acid-base titration. The remaining IEC after $72 \mathrm{~h}$ of aging $(0.93 \mathrm{meq} / \mathrm{g})$, amounts to $76 \%$ of the initial value $(1.23 \mathrm{meq} / \mathrm{g})$, which is higher than for ionomers based on PPO with a long spacer chain (52\%) [24]. The lower degradation rate of poly(VBCl-co-hexene) corroborates that ionomers without ether groups are less sensitive to the $S_{N} 2$ attack [68]. The degradation of benzyl alkylammonium cations seems to be triggered by ether cleavage of the main chain $[69,70]$. Furthermore, the presence of a long side chain in the benzyl alkyl ammonium cations contributes to slowing down the $\mathrm{S}_{\mathrm{N}} 2$ reaction rate through steric hindrance. 


\subsection{Thermogravimetry of the Crosslinked Ionomer}

The thermogram of the crosslinked ionomer (Figure 7a) shows an initial mass decrease of about $9 \%$ of the sample mass below $100{ }^{\circ} \mathrm{C}$, which is related to the loss of water. The large loss of water is in agreement with the high water uptake of the ionomer and the number of positive charges present on the backbone. The second broad peak between $130{ }^{\circ} \mathrm{C}$ and more than $200{ }^{\circ} \mathrm{C}$ corresponding to $12 \%$ of the sample mass can be attributed to the two amines present in the ionomer. Similar decomposition temperatures were reported in various references [71,72].
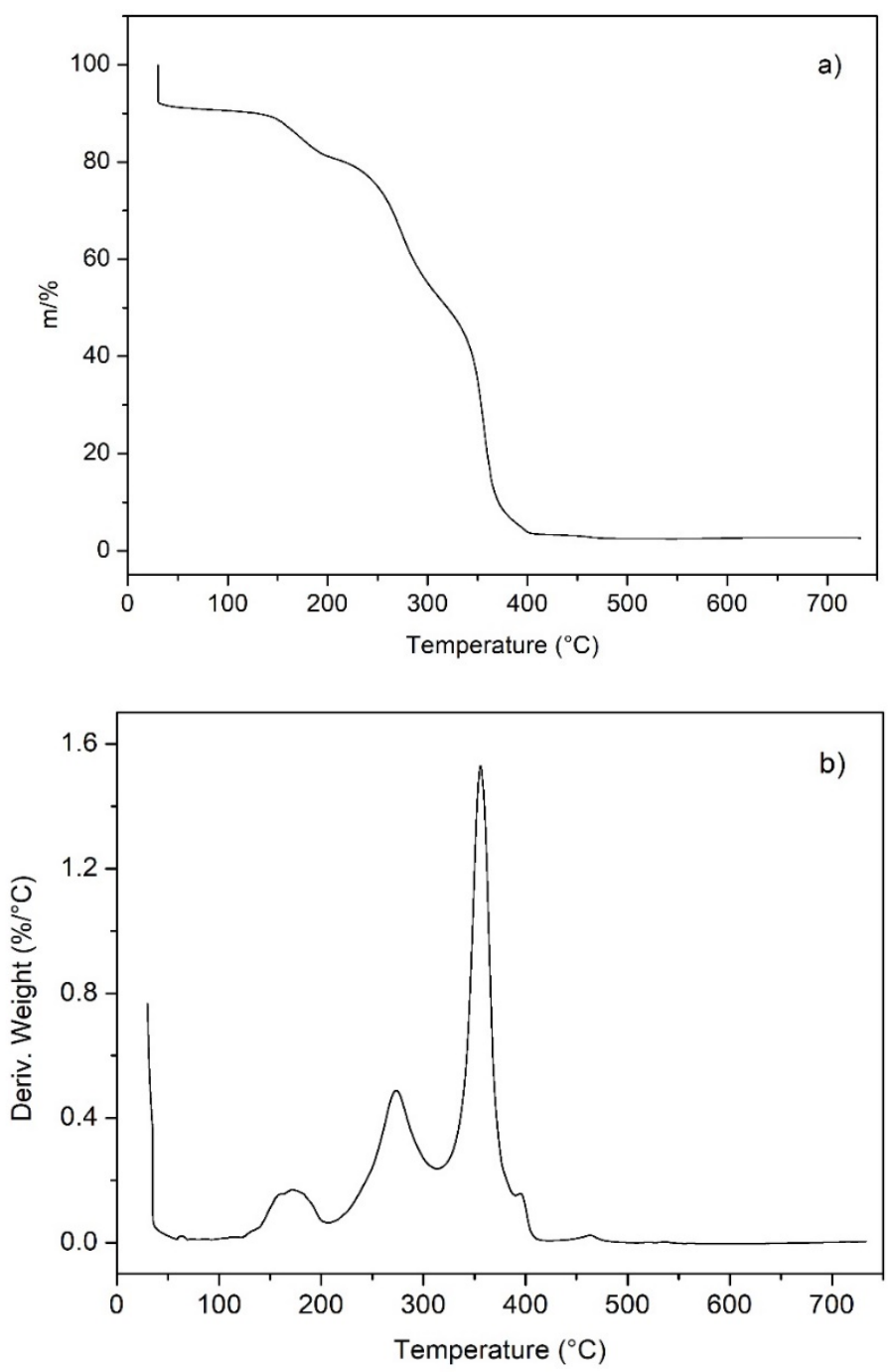

Figure 7. (a) High-resolution thermogram of the crosslinked ionomer in air; (b) derivative curve.

The second peak observed in the Figure $7 \mathrm{~b}$ from $210{ }^{\circ} \mathrm{C}$ to $310^{\circ} \mathrm{C}$ can be attributed to the thermal degradation of benzyl chloride moieties [73], it corresponds to about $30 \%$. The sharp peak observed around $360^{\circ} \mathrm{C}$ with a mass loss around $50 \%$ corresponds to the thermal degradation of the aliphatic poly(ethylene-co-hexene) backbone. Small peaks around $400{ }^{\circ} \mathrm{C}$ and $465^{\circ} \mathrm{C}$ are probably due to the degradation of small amounts of poly(1-hexene) homopolymer formed during the polymerization reaction. These homopolymers decompose between 400 and $470{ }^{\circ} \mathrm{C}$ [74].

\subsection{Water Uptake and Ionic Conductivity of Blend Membrane with PVA}

The crosslinked ionomer was blended with $20 \%$ of poly(vinyl alcohol) (PVA) and was further crosslinked with glutaraldehyde in acid conditions as described in Section 3.5 to 
enhance its mechanical properties. The intrinsic properties of PVA, such as water solubility, nontoxicity, biodegradability, film forming properties, and low cost, make it an excellent choice. Its ability to form composites and the common use as an absorbent for alkaline solutions, giving it ionic conducting properties, make it appropriate for our purpose [75-77].

The WU of the blend membrane was $110 \%$ at $25^{\circ} \mathrm{C}$, while pristine PVA and crosslinked PVA presented a WU of $170 \%$ and $78 \%$ respectively. The WU is in the right order to avoid excessive swelling, but still guarantee a high hydroxide ion mobility.

The impedance spectrum of the poly(VBCl-hexene)/PVA blend membrane at $25^{\circ} \mathrm{C}$ is shown in Figure 8. The sample resistance is determined at the intersection of the curve with the real axis.

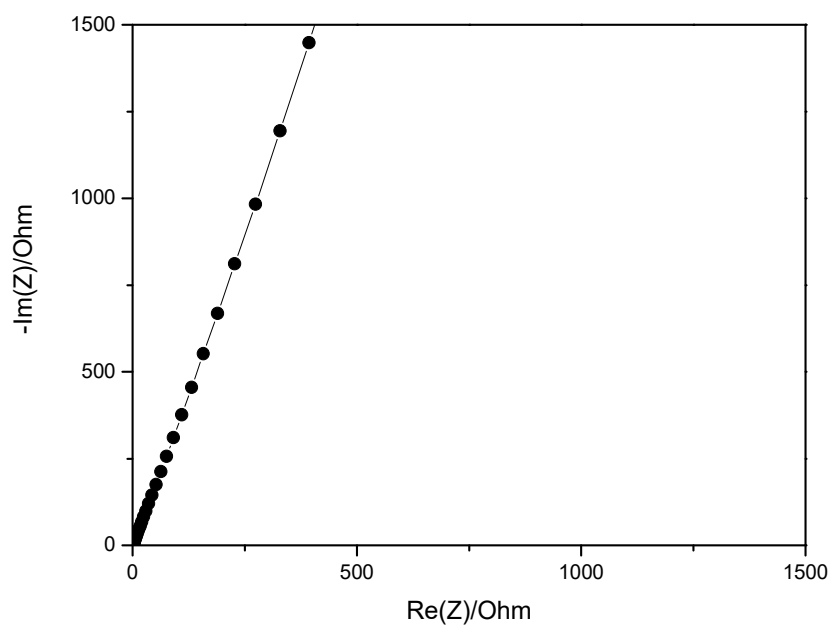

Figure 8. Impedance spectrum of poly(VBCl-hexene)/PVA blend membrane at $25^{\circ} \mathrm{C}$.

The through-plane ionic conductivity of the blend membrane, calculated according to eq. 1 , is reported in Table 2 as function of the temperature.

Table 2. Ionic conductivity of blend membrane in $\mathrm{OH}^{-}$form.

\begin{tabular}{cc}
\hline Temperature $\left({ }^{\circ} \mathbf{C}\right)$ & Conductivity $(\mathbf{m S} / \mathbf{c m})$ \\
\hline 25 & 29.5 \\
\hline 60 & 32.2 \\
\hline 80 & 34.8 \\
\hline 25 (After cooling down) & 27.6 \\
\hline
\end{tabular}

One can notice a relatively high ionic conductivity at $25^{\circ} \mathrm{C}$ showing that the ion conduction channels are well connected in the blend, because PVA presents a high hydrophilicity. The PVA blend formation is a valid strategy for obtaining high conductivity membranes that are useful for practical applications.

The activation energy $E_{A}$ can be determined from the temperature dependence of the ionic conductivity $\sigma$ according to the Arrhenius equation:

$$
\ln \sigma=A-\frac{E_{A}}{R T}
$$

The activation energy is very low $(0.03 \mathrm{eV})$, which is consistent with hydroxide ion transport in aqueous solution, confirming that the PVA can participate in the ionic transport. 


\section{Materials and Methods}

\subsection{Reagents}

4-Vinylbenzyl chloride $(\mathrm{VBCl}, 90 \%$; the stabilizer was removed by washing with a $1 \mathrm{M} \mathrm{NaOH}$ solution), 1-hexene ( $\geq 99 \%), \mathrm{ZrCl}_{4}(\mathrm{THF})_{2}$ (zirconium (IV) chloride tetrahydrofuran complex (1:2)), $\mathrm{AlCl}_{3}$ (anhydrous ReagentPlus ${ }^{\circledR}, 99 \%$ ), methyl iodide (MeI, purum, $\geq 99.0 \%$ ), poly(vinyl alcohol) (PVA, 89-98000 Mw 99\% hydrolyzed), were purchased from Sigma-Aldrich. NMP, N,N-dimethylhexylamine, and $\mathrm{N}, \mathrm{N}, \mathrm{N}^{\prime}, \mathrm{N}^{\prime}$-tetramethylethylene diamine (TEMED) were purchased from TCI.

\subsection{Synthesis of Poly(VBCl-co-hexene)}

\subsubsection{Synthesis of the Cocatalyst}

$\mathrm{AlCl}_{3}(0.23 \mathrm{~g}, 1.9 \mathrm{mmol})$ and methyl iodide $(0.1 \mathrm{~mL}, 1.6 \mathrm{mmol})$ were added to a round-bottom flask and mixed under $\mathrm{N}_{2}$ atmosphere for $30 \mathrm{~min}$.

\subsubsection{Catalyst Activation}

The complex $\mathrm{ZrCl}_{4}(\mathrm{THF})_{2}(0.250 \mathrm{~g}, 0.55 \mathrm{mmol})$ and the cocatalyst were mixed. The mixture was kept under stirring conditions for $1 \mathrm{~h}$ at room temperature. The color changed from light yellow to dark violet after the catalyst activation.

\subsubsection{Random Copolymerization}

The mixture of the monomers hexene $(28 \mathrm{mmol}, 4 \mathrm{~mL})$ and $\mathrm{VBCl}(14 \mathrm{mmol}, 1.93 \mathrm{~mL})$ was added to the activated catalyst with a $\mathrm{N}_{2}$ atmosphere. The system was kept under strong agitation at $60^{\circ} \mathrm{C}$. During the first $3 \mathrm{~h}$ the viscosity notably increased, the coloration of the monomer mixture changed from yellow to red. We attributed the coloration change to the formation of the complex between the catalyst and the monomer. To ensure the complete conversion, the reaction was carried out for $18 \mathrm{~h}$, after this time a gel was obtained. To deactivate the complex $20 \mathrm{~mL}$ of $2 \mathrm{M} \mathrm{HCl}$ in $100 \mathrm{~mL}$ of methanol was added; the colour changed from red to strong yellow. The polymer was purified by dissolution in chloroform and precipitation in methanol. The final product was dried in an oven at $60{ }^{\circ} \mathrm{C}$. The ${ }^{1} \mathrm{H}-$ NMR spectrum in $\mathrm{CDCl}_{3}$ showed that the amount of chloromethylated moieties in the polymer was around 30\%.

\subsection{Crosslinking of the Copolymer with TEMED}

The purified copolymer $(0.7 \mathrm{~g}, 6.2 \mathrm{mmol})$ was dissolved in NMP. Then the crosslinker (TEMED $0.37 \mathrm{mmol}, 0.06 \mathrm{~mL}$ ) was added: the amine amount was around $20 \%$ of the chloromethylated moieties of the co-polymer. The reaction was kept at $80{ }^{\circ} \mathrm{C}$ for $26 \mathrm{~h}$.

\subsection{Ionomer Quaternization}

The unreacted chloromethylated moieties were quaternized with an excess of N,Ndimethylhexylamine $(0.3 \mathrm{~mL}, 1.77 \mathrm{mmol})$ for $72 \mathrm{~h}$ at $80^{\circ} \mathrm{C}$. After the reaction, the ionomer was precipitated in diethylether. Then the ionomer was washed with water, dried over $\mathrm{P}_{2} \mathrm{O}_{5}$ and the ${ }^{1} \mathrm{H}-\mathrm{NMR}$ spectrum in $\mathrm{d}_{6}$-DMSO was recorded.

\subsection{Membrane Fabrication}

$18.75 \mathrm{mg}$ of PVA (20\% by weight with respect to the quaternized ionomer) was dissolved in hot bidistilled water $\left(80^{\circ} \mathrm{C}\right)$ under strong stirring $(10 \mathrm{~min}, 600 \mathrm{rpm})$. The hot polymer solution (quaternized ionomer, $75 \mathrm{mg}$ in $5 \mathrm{~mL}$ of NMP) was suddenly added to the PVA solution and mixed for about $10 \mathrm{~min}$. After this time glutaraldehyde ( $5 \%$ by weight with respect to the PVA) in $50 \mathrm{wt} \%$ water solution was added. Later, 4 drops of concentrated $\mathrm{HCl}$ were added and the stirring was maintained for $10 \mathrm{~min}$ at $\mathrm{RT}$. The solution was poured into a Teflon petri dish, and then placed in an oven at $85^{\circ} \mathrm{C}$ for 3 days. The membrane was peeled off and washed with bidistilled water and then exchanged with $2 \mathrm{M} \mathrm{KCl}$ for 2 days at RT to obtain the chloride form. The membrane was washed again in bidistilled water to eliminate excess $\mathrm{KCl}$. 


\subsection{Stability Test}

The stability test was performed on the ionomer in powder form. The powder was treated in $2 \mathrm{M} \mathrm{NaOH}$ at $80^{\circ} \mathrm{C}$ for $72 \mathrm{~h}$, then washed with deionized water to remove excess sodium hydroxide. The IEC was measured as described below.

\subsection{Determination of Ion Exchange Capacity (IEC) by Back-Titration}

The ionomers were immersed $24 \mathrm{~h}$ in $2 \mathrm{M} \mathrm{NaOH}$ at $\mathrm{RT}$, then washed in deionized water. After drying over $\mathrm{P}_{2} \mathrm{O}_{5}$ for $72 \mathrm{~h}$, they were weighed and immersed in a $0.018 \mathrm{~N}$ $\mathrm{HCl}$ solution. The acidic solution was then backtitrated with $0.022 \mathrm{~N} \mathrm{NaOH}$. The IEC of the pristine ionomer was $1.23 \mathrm{meq} / \mathrm{g}$ and after the degradation test the IEC decreased to $0.93 \mathrm{meq} / \mathrm{g}$.

\subsection{NMR Spectroscopy}

${ }^{1} \mathrm{H}-\mathrm{NMR}$ spectroscopy was performed using a Bruker AVANCE 400 apparatus ( $400.13 \mathrm{MHz}$ ) using deuterated solvents $\left(\mathrm{CDCl}_{3}, \mathrm{~d}_{6}\right.$-DMSO). Chemical shifts were referenced to tetramethylsilane.

\subsection{FTIR Spectroscopy}

The FTIR spectrum was recorded in a wavenumber range $500-4000 \mathrm{~cm}^{-1}$ using a Perkin Elmer Spectrum 2 IR spectrometer (Waltham, MA, USA) equipped with an ATR crystal diamond module. The sample was dried before the test.

\subsection{Thermogravimetry}

The thermal stability of the polymer was investigated between 30 and $700{ }^{\circ} \mathrm{C}$ by high resolution thermogravimetric analysis using a platinum sample holder (TGA Q500, TA Instruments) with a heating rate of $3 \mathrm{~K} \mathrm{~min}^{-1}$.

\subsection{Ionic Conductivity}

The through-plane ionic conductivity of the blend membrane was measured between 25 and $80^{\circ} \mathrm{C}$ by impedance spectrometry between $1 \mathrm{~Hz}$ and $6 \mathrm{MHz}$ using an impedance spectrometer Biologic VSP300. The amplitude of the oscillating voltage was $20 \mathrm{mV}$. Before the test the membrane was immersed for $24 \mathrm{~h}$ at $25^{\circ} \mathrm{C}$ in a $2 \mathrm{M} \mathrm{KOH}$ solution and rapidly washed with deionized water to remove as much as possible of excess $\mathrm{KOH}$ solution. The test was performed using a custom-made Swagelok cell with two stainless steel electrodes in fully humidified conditions. The ionic conductivity $\sigma$ was calculated using the Equation (2):

$$
\sigma=\frac{t h}{R * A}
$$

where th and A are respectively the thickness (measured with a micrometer Mitutoyo 293-230) and the electrode area.

\section{Conclusions}

The copolymerization of $\mathrm{VBCl}$ and hexene by $\mathrm{ZNp}$ employing $\mathrm{ZrCl}_{4}(\mathrm{THF})_{2}$ catalyst was successful. The prepared copolymer and derived anion exchange ionomer were not previously reported in the literature. The stability test in alkaline conditions of the ionomer showed that the remaining IEC after $72 \mathrm{~h}$ was $76 \%$ of the initial value, which is higher than for the ionomers based on PPO studied previously in our laboratory, confirming that AEMs based on polymer backbones without ether linkage, such as polynorbornenes, are superior with regards to degradation in alkaline environment.

The copolymer was crosslinked with TEMED and then quaternized with $\mathrm{N}, \mathrm{N}$-dimethylhexylamine to increase the IEC and to avoid excessive swelling. Similar crosslinking approaches were reported with good results for cation conducting polymers, such as sulfonated poly(ether ether ketone). 
The presence of isotactic segments of poly(1-hexene) might be employed in future works to enhance the mechanical properties of the membranes and to obtain a membrane based on just poly(VBCl-co-hexene).

The crosslinked ionomer was also blended with 20\% of PVA and then crosslinked with glutaraldehyde. The handling experience showed good mechanical properties, as well as good hydrolytic stability. The conductivity is in the order of $30 \mathrm{mS} / \mathrm{cm}$ above that of PPO-based membranes reported in our previous works. The higher WU compared with PPO membranes may promote a better connectivity of hydrophilic domains facilitating hydroxide ion transport.

Author Contributions: Conceptualization, R.A.B.-A., R.N., M.L.D.V.; methodology, R.A.B.-A., M.L.D.V. and G.E.; software, R.A.B.-A., R.N., L.P. and P.K.; validation R.A.B.-A., R.N. and L.P.; formal analysis, R.A.B.-A., R.N. and L.P.; investigation, R.A.B.-A., R.N. and L.P.; resources, M.L.D.V., P.K. and G.E.; data curation, R.A.B.-A., R.N., L.P., M.L.D.V. and P.K.; writing-original draft preparation, R.A.B.-A. and R.N.; writing-review and editing, R.N., R.A.B.-A., M.L.D.V. and P.K.; supervision, M.L.D.V., P.K. and G.E. All authors have read and agreed to the published version of the manuscript.

Funding: R.A.B.-A. gratefully acknowledges the co-tutela grants by the Franco-Italian University (Vinci program).

Institutional Review Board Statement: Not applicable.

Informed Consent Statement: Not applicable.

Conflicts of Interest: The authors declare no conflict of interest.

Sample Availability: Samples of the compounds are not available from the authors.

\section{References}

1. Varcoe, J.R.; Slade, R.C.T. Prospects for alkaline anion-exchange membranes in low temperature fuel cells. Fuel Cells 2005, 5, 187-200. [CrossRef]

2. Couture, G.; Alaaeddine, A.; Boschet, F.; Ameduri, B. Polymeric materials as anion-exchange membranes for alkaline fuel cells. Prog. Polym. Sci. 2011, 36, 1521-1557. [CrossRef]

3. Hickner, M.A.; Herring, A.M.; Coughlin, E.B. Anion Exchange Membranes: Current Status and Moving Forward. J. Polym. Sci. Part B Polym. Phys. 2013, 51, 1727-1735. [CrossRef]

4. Chen, N.; Lee, Y.M. Anion exchange polyelectrolytes for membranes and ionomers. Prog. Polym. Sci. 2021, 113, 101345. [CrossRef]

5. Marini, S.; Salvi, P.; Nelli, P.; Pesenti, R.; Villa, M.; Berrettoni, M.; Zangari, G.; Kiros, Y. Advanced alkaline water electrolysis Electrochim. Acta 2012, 82, 384-391. [CrossRef]

6. Carrette, L.; Friedrich, K.A.; Stimming, U. Fuel Cell-Fundamentals and Applications. Fuel Cells 2001, 1, 5-39. [CrossRef]

7. Weber, A.Z.; Mench, M.M.; Meyers, J.P.; Ross, P.N.; Gostick, J.T.; Liu, Q.H. Redox flow batteries: A review. J. Appl. Electrochem. 2011, 41, 1137-1164. [CrossRef]

8. Pan, Z.F.; An, L.; Zhao, T.S.; Tang, Z.K. Advances and challenges in alkaline anion exchange membrane fuel cells. Prog. Energy Combust. Sci. 2018, 66, 141-175. [CrossRef]

9. Mai, Z.S.; Zhang, H.M.; Zhang, H.Z.; Xu, W.X.; Wei, W.P.; Na, H.; Li, X.F. Anion-Conductive Membranes with Ultralow Vanadium Permeability and Excellent Performance in Vanadium Flow Batteries. Chemsuschem 2013, 6, 328-335. [CrossRef]

10. Chu, X.M.; Liu, L.; Huang, Y.D.; Guiver, M.D.; Li, N.W. Practical implementation of bis-six-membered N-cyclic quaternary ammonium cations in advanced anion exchange membranes for fuel cells: Synthesis and durability. J. Membr. Sci. 2019, 578, 239-250. [CrossRef]

11. Becerra-Arciniegas, R.A.; Narducci, R.; Ercolani, G.; Antonaroli, S.; Sgreccia, E.; Pasquini, L.; Knauth, P.; Di Vona, M.L. Alkaline stability of model anion exchange membranes based on poly(phenylene oxide) (PPO) with grafted quaternary ammonium groups: Influence of the functionalization route. Polymer 2019, 185, 121931. [CrossRef]

12. Bauer, B.; Strathmann, H.; Effenberger, F. Anion-exchange membranes with improved alkaline stability. Desalination 1990, 79, 125-144. [CrossRef]

13. Marino, M.G.; Kreuer, K.D. Alkaline Stability of Quaternary Ammonium Cations for Alkaline Fuel Cell Membranes and Ionic Liquids. Chemsuschem 2015, 8, 513-523. [CrossRef] [PubMed]

14. Chen, J.J.; Li, C.P.; Wang, J.C.; Li, L.; Wei, Z.D. A general strategy to enhance the alkaline stability of anion exchange membranes. J. Mater. Chem. A 2017, 5, 6318-6327. [CrossRef]

15. Cheng, J.; He, G.H.; Zhang, F.X. A mini-review on anion exchange membranes for fuel cell applications: Stability issue and addressing strategies. Int. J. Hydrogen Energy 2015, 40, 7348-7360. [CrossRef] 
16. Pandey, T.P.; Sarode, H.N.; Yang, Y.T.; Yang, Y.; Vezzu, K.; Di Noto, V.; Seifert, S.; Knauss, D.M.; Liberatore, M.W.; Herring, A.M. A Highly Hydroxide Conductive, Chemically Stable Anion Exchange Membrane, Poly(2,6 dimethyl 1,4 phenylene oxide)-bPoly(vinyl benzyl trimethyl ammonium), for Electrochemical Applications. J. Electrochem. Soc. 2016, 163, H513-H520. [CrossRef]

17. Narducci, R.; Ercolani, G.; Becerra-Arciniegas, R.A.; Pasquini, L.; Knauth, P.; Di Vona, M.L. "Intrinsic" Anion Exchange Polymers through the Dissociation of Strong Basic Groups: PPO with Grafted Bicyclic Guanidines. Membranes 2019, 9, 57. [CrossRef]

18. You, W.; Noonan, K.J.T.; Coates, G.W. Alkaline-stable anion exchange membranes: A review of synthetic approaches. Prog. Polym. Sci. 2020, 100, 101177. [CrossRef]

19. Zhang, M.; Liu, J.L.; Wang, Y.G.; An, L.A.; Guiver, M.D.; Li, N.W. Highly stable anion exchange membranes based on quaternized polypropylene. J. Mater. Chem. A 2015, 3, 12284-12296. [CrossRef]

20. Lin, C.X.; Wang, X.Q.; Hu, E.N.; Yang, Q.; Zhang, Q.G.; Zhu, A.M.; Liu, Q.L. Quaternized triblock polymer anion exchange membranes with enhanced alkaline stability. J. Membr. Sci. 2017, 541, 358-366.

21. Dang, H.S.; Jannasch, P. Exploring Different Cationic Alkyl Side Chain Designs for Enhanced Alkaline Stability and Hydroxide Ion Conductivity of Anion-Exchange Membranes. Macromolecules 2015, 48, 5742-5751. [CrossRef]

22. Zhu, L.; Yu, X.D.; Hickner, M.A. Exploring backbone-cation alkyl spacers for multi-cation side chain anion exchange membranes. J. Power Sources 2018, 375, 433-441. [CrossRef]

23. Long, H.; Kim, K.; Pivovar, B.S. Hydroxide Degradation Pathways for Substituted Trimethylammonium Cations: A DFT Study. J. Phys. Chem. C 2012, 116, 9419-9426. [CrossRef]

24. Becerra-Arciniegas, R.A.; Narducci, R.; Ercolani, G.; Sgreccia, E.; Pasquini, L.; Di Vona, M.L.; Knauth, P. Model Long Side-Chain PPO-Based Anion Exchange Ionomers: Properties and Alkaline Stability. J. Phys. Chem. C 2020, 124, 1309-1316. [CrossRef]

25. Di Vona, M.L.; Narducci, R.; Pasquini, L.; Pelzer, K.; Knauth, P. Anion-conducting ionomers: Study of type of functionalizing amine and macromolecular cross-linking. Int. J. Hydrogen Energy 2014, 39, 14039-14049. [CrossRef]

26. Di Vona, M.L.; Casciola, M.; Donnadio, A.; Nocchetti, M.; Pasquini, L.; Narducci, R.; Knauth, P. Anionic conducting composite membranes based on aromatic polymer and layered double hydroxides. Int. J. Hydrogen Energy 2017, 42, 3197-3205. [CrossRef]

27. Pizzoferrato, R.; Ciotta, E.; Ferrari, I.V.; Narducci, R.; Pasquini, L.; Varone, A.; Richetta, M.; Antonaroli, S.; Braglia, M.; Knauth, P.; et al. Layered Double Hydroxides Containing an Ionic Liquid: Ionic Conductivity and Use in Composite Anion Exchange Membranes. Chemelectrochem 2018, 5, 2781-2788. [CrossRef]

28. Pasquini, L.; Becerra-Arciniegas, R.A.; Narducci, R.; Sgreccia, E.; Gressel, V.; Di Vona, M.L.; Knauth, P. Properties and Alkaline Stability of Composite Anion Conducting Ionomers Based on Poly(phenylene oxide) Grafted with DABCO and Mg/Al Lamellar Double Hydroxide. Chemelectrochem 2020, 7, 2917-2924. [CrossRef]

29. Narducci, R.; Sgreccia, E.; Di Vona, M.L.; Knauth, P. Anion Exchange Membranes with 1D, 2D and 3D Fillers: A Review. Polymers 2021, 13, 3887. [CrossRef] [PubMed]

30. Lee, W.H.; Kim, Y.S.; Bae, C. Robust Hydroxide Ion Conducting Poly(biphenyl alkylene)s for Alkaline Fuel Cell Membranes. ACS Macro Lett. 2015, 4, 814-818. [CrossRef]

31. Pham, T.H.; Olsson, J.S.; Jannasch, P. Poly(arylene alkylene)s with pendant N-spirocyclic quaternary ammonium cations for anion exchange membranes. J. Mater. Chem. A 2018, 6, 16537-16547. [CrossRef]

32. Chen, N.J.; Lu, C.R.; Li, Y.X.; Long, C.; Li, Z.M.; Zhu, H. Tunable multi-cations-crosslinked poly(arylene piperidinium)-based alkaline membranes with high ion conductivity and durability. J. Membr. Sci. 2019, 588, 117120. [CrossRef]

33. Long, C.A.; Wang, Z.H.; Zhu, H. High chemical stability anion exchange membrane based on poly(aryl piperidinium): Effect of monomer configuration on membrane properties. Int. J. Hydrogen Energy 2021, 46, 18524-18533. [CrossRef]

34. Zhou, X.X.; Wu, L.X.; Zhang, G.X.; Li, R.Y.; Hu, X.; Chang, X.W.; Shen, Y.H.; Liu, L.; Li, N.W. Rational design of comb-shaped poly(arylene indole piperidinium) to enhance hydroxide ion transport for $\mathrm{H}_{2} / \mathrm{O}_{2}$ fuel cell. J. Membr. Sci. 2021, 631,119335 . [CrossRef]

35. Shirbakht, S.; Mirmohammadi, S.A.; Didehban, K.; Sadjadi, S.; Bahri-Laleh, N. Effects of monomer length on alpha-olefins polymerization using a conventional Ziegler-Natta catalyst. Adv. Polym. Technol. 2018, 37, 2588-2596. [CrossRef]

36. Talapatra, S.; Rao, P.V.C.; Ravindranathan, M. Copolymerization of propylene and styrene with Ziegler-Natta catalyst systems: Thermal and spectroscopic characterization of the products. Eur. Polym. J. 1999, 35, 1073-1078. [CrossRef]

37. Soga, K.; Uozumi, T.; Yanagihara, H.; Siono, T. Polymerization of styrene with heterogeneous Ziegler-Natta catalysts. Makromol. Chem. Rapid Commun. 1990, 11, 229-234. [CrossRef]

38. Shamiri, A.; Chakrabarti, M.H.; Jahan, S.; Hussain, M.A.; Kaminsky, W.; Aravind, P.V.; Yehye, W.A. The Influence of Ziegler-Natta and Metallocene Catalysts on Polyolefin Structure, Properties, and Processing Ability. Materials 2014, 7, 5069-5108. [CrossRef] [PubMed]

39. Gambarotta, S. Vanadium-based Ziegler-Natta: Challenges, promises, problems. Coord. Chem. Rev. 2003, 237, 229-243. [CrossRef]

40. Claverie, J.R.; Schaper, F. Ziegler-Natta catalysis: 50 years after the Nobel Prize. Mrs Bull. 2013, 38, 213-218. [CrossRef]

41. Zhu, L.; Yu, X.D.; Peng, X.; Zimudzi, T.J.; Saikia, N.; Kwasny, M.T.; Song, S.F.; Kushner, D.I.; Fu, Z.S.; Tew, G.N.; et al. Poly(olefin)Based Anion Exchange Membranes Prepared Using Ziegler-Natta Polymerization. Macromolecules 2019, 52, 4030-4041. [CrossRef]

42. Mandal, M.; Huang, G.; Ul Hassan, N.; Mustain, W.E.; Kohl, P.A. Poly(norbornene) anion conductive membranes: Homopolymer, block copolymer and random copolymer properties and performance. J. Mater. Chem. A 2020, 8, 17568-17578. [CrossRef] 
43. Chen, W.T.; Mandal, M.; Huang, G.; Wu, X.M.; He, G.H.; Kohl, P.A. Highly Conducting Anion-Exchange Membranes Based on Cross-Linked Poly(norbornene): Ring Opening Metathesis Polymerization. ACS Appl. Energy Mater. 2019, 2, $2458-2468$. [CrossRef]

44. Proto, A.; Capacchione, C.; Motta, O.; De Carlo, F. $\mathrm{ZrCl}_{4}$ as catalyst for olefins and styrene polymerization: Effect of ethereal donors on the activity and stereospecificity. Macromolecules 2003, 36, 5942-5946. [CrossRef]

45. Niyomthai, T.; Jongsomjit, B.; Praserthdam, P. Impact of $\mathrm{AlCl}_{3}$ and $\mathrm{FeCl}_{2}$ Addition on Catalytic Behaviors of $\mathrm{TiCl}_{4} / \mathrm{MgCl}_{2} / \mathrm{THF}$ Catalysts for Ethylene Polymerization and Ethylene/1-Hexene Copolymerization. Bull. Chem. React. Eng. Catal. 2018, 13, 393-404. [CrossRef]

46. Bradley, D.C.; Abd-el Halim, F.M.; Wardlaw, W. The chloride ethoxides of zirconium. J. Chem. Soc. 1950, 676, 3450-3454. [CrossRef]

47. Soto, M.; Hiller, M.; Oschkinat, H.; Koschek, K. Multifunctional Benzoxazines Feature Low Polymerization Temperature and Diverse Polymer Structures. Polymers 2016, 8, 278. [CrossRef] [PubMed]

48. Vengatesan, S.; Vasudevan, D.; Radhakrishnan, S. Time- and temperature-resolved in-situ NMR studies on simultaneous quaternization/cross-linking of poly(vinylbenzyl chloride) polymer with hexamine. Colloid Polym. Sci. 2015, 293, 3439-3448. [CrossRef]

49. Szczegot, K.; Flisak, Z.; Sibelska, I.; Dawidowska-Marynowicz, B. Transition metal chlorides complexes with tetrahydrofuran $\mathrm{MtCl}(4)(\mathrm{THF})(2)$ used as precursors of ethylene polymerization catalysts. Polimery 2002, 47, 85-89. [CrossRef]

50. Proto, A.; Luciano, E.; Capacchione, C.; Motta, $\mathrm{O} . \mathrm{ZrCl}_{4}(\mathrm{THF})_{2} /$ methylaluminoxane as the catalyst for the syndiotactic polymerization of styrene. Macromol. Rapid Commun. 2002, 23, 183-186. [CrossRef]

51. Zhang, Y.X.; Wang, C.Q.; Mecking, S.; Jian, Z.B. Ultrahigh Branching of Main-Chain-Functionalized Polyethylenes by Inverted Insertion Selectivity. Angew. Chem. Int. Ed. 2020, 59, 14296-14302. [CrossRef]

52. Alhan, H.B.E.; Jones, G.R.; Harth, E. Branching Regulation in Olefin Polymerization via Lewis Acid Triggered Isomerization of Monomers. Angew. Chem. Int. Ed. 2020, 59, 4743-4749. [CrossRef]

53. Ertem, S.P.; Caire, B.R.; Tsai, T.H.; Zeng, D.; Vandiver, M.A.; Kusoglu, A.; Seifert, S.; Hayward, R.C.; Weber, A.Z.; Herring, A.M.; et al. Ion Transport Properties of Mechanically Stable Symmetric ABCBA Pentablock Copolymers with Quaternary Ammonium Functionalized Midblock. J. Polym. Sci. Part B Polym. Phys. 2017, 55, 612-622. [CrossRef]

54. Lin, B.C.; Xu, F.; Su, Y.; Zhu, Z.J.; Ren, Y.R.; Ding, J.N.; Yuan, N.Y. Facile Preparation of Anion-Exchange Membrane Based on Polystyrene-b-polybutadiene-b-polystyrene for the Application of Alkaline Fuel Cells. Ind. Eng. Chem. Res. 2019, 58, 22299-22305. [CrossRef]

55. Cao, Y.C.; Wang, X.; Mamlouk, M.; Scott, K. Preparation of alkaline anion exchange polymer membrane from methylated melamine grafted poly(vinylbenzyl chloride) and its fuel cell performance. J. Mater. Chem. 2011, 21, 12910-12916. [CrossRef]

56. Wang, C.; Mo, B.M.; He, Z.F.; Shao, Q.; Pan, D.; Wujick, E.; Guo, J.; Xie, X.L.; Xie, X.F.; Guo, Z.H. Crosslinked norbornene copolymer anion exchange membrane for fuel cells. J. Membr. Sci. 2018, 556, 118-125. [CrossRef]

57. Cheng, C.W.; He, X.H.; Huang, S.M.; Zhang, F.; Guo, Y.; Wen, Y.F.; Wu, B.; Chen, D.F. Novel self-cross-linked multi-imidazolium cations long flexible side chains triblock copolymer anion exchange membrane based on ROMP-type polybenzonorbornadiene. Int. J. Hydrogen Energy 2020, 45, 19676-19690. [CrossRef]

58. Ponce-Gonzalez, J.; Whelligan, D.K.; Wang, L.Q.; Bance-Soualhi, R.; Wang, Y.; Peng, Y.Q.; Peng, H.Q.; Apperley, D.C.; Sarode, H.N.; Pandey, T.P.; et al. High performance aliphatic-heterocyclic benzyl-quaternary ammonium radiation-grafted anion-exchange membranes. Energy Environ. Sci. 2016, 9, 3724-3735. [CrossRef]

59. Yu, J.S.; Wu, F.G.; Zhou, Y.; Zheng, Y.Z.; Yu, Z.W. Selective recognition induced nanostructures in a cucurbit 7 uril-based host-guest system: Micelles, nanorods and nanosheets. Phys. Chem. Chem. Phys. 2012, 14, 8506-8510. [CrossRef] [PubMed]

60. Nhung, L.T.T.; Kim, I.Y.; Yoon, Y.S. Quaternized Chitosan-Based Anion Exchange Membrane Composited with Quaternized Poly(vinylbenzyl chloride)/Polysulfone Blend. Polymers 2020, 12, 2714. [CrossRef] [PubMed]

61. Vengatesan, S.; Santhi, S.; Jeevanantham, S.; Sozhan, G. Quaternized poly (styrene-co-vinylbenzyl chloride) anion exchange membranes for alkaline water electrolysers. J. Power Sources 2015, 284, 361-368. [CrossRef]

62. Wang, X.Y.; Zhang, X.; Wu, C.M.; Han, X.Z.; Xu, C. Anion exchange membranes with excellent monovalent anion perm-selectivity for electrodialysis applications. Chem. Eng. Res. Des. 2020, 158, 24-32. [CrossRef]

63. Braglia, M.; Ferrari, I.V.; Djenizian, T.; Kaciulis, S.; Soltani, P.; Di Vona, M.L.; Knauth, P. Bottom-Up Electrochemical Deposition of Poly(styrene sulfonate) on Nanoarchitectured Electrodes. ACS Appl. Mater. Interfaces 2017, 9, 22902-22910. [CrossRef] [PubMed]

64. Fang, J.F.; Xuan, Y.M.; Li, Q.A. Preparation of polystyrene spheres in different particle sizes and assembly of the PS colloidal crystals. Sci. China Technol. Sci. 2010, 53, 3088-3093. [CrossRef]

65. Yan, Y.B.; Wang, D.F.; He, S.Y.; Ren, H.G.; Xu, Y.J. Study on the synthesis of hexene-1 catalyzed by Ziegler-Natta catalyst and polyhexene-1 applications. E-Polym. 2019, 19, 511-518. [CrossRef]

66. Hanifpour, A.; Bahri-Laleh, N.; Nekoomanesh-Haghighi, M.; Karimi, M. Study on unsaturated structure and tacticity of poly1hexene and new copolymer of 1-hexene/5-hexene-1-ol prepared by metallocene catalyst. J. Organomet. Chem. 2016, 819, 103-108. [CrossRef]

67. Ruiz-Orta, C.; Fernandez-Blazquez, J.P.; Pereira, E.J.; Alamo, R.G. Time-resolved FTIR spectroscopic study of the evolution of helical structure during isothermal crystallization of propylene 1-hexene copolymers. Identification of regularity bands associated with the trigonal polymorph. Polymer 2011, 52, 2856-2868. [CrossRef] 
68. Nunez, S.A.; Hickner, M.A. Quantitative H-1 NMR Analysis of Chemical Stabilities in Anion-Exchange Membranes. ACS Macro Lett. 2013, 2, 49-52. [CrossRef]

69. Miyanishi, S.; Yamaguchi, T. Ether cleavage-triggered degradation of benzyl alkylammonium cations for polyethersulfone anion exchange membranes. Phys. Chem. Chem. Phys. 2016, 18, 12009-12023. [CrossRef]

70. Park, E.J.; Kim, Y.S. Quaternized aryl ether-free polyaromatics for alkaline membrane fuel cells: Synthesis, properties, and performance-A topical review. J. Mater. Chem. A 2018, 6, 15456-15477. [CrossRef]

71. Yadav, V.; Rathod, N.H.; Kulshrestha, V. Series-Connected Tetracation Partially Cross-Linked Anion Exchange Membranes: Insight towards Consequences of Alkyl Spacer Length. ACS Appl. Polym. Mater. 2021, 3, 3307-3320. [CrossRef]

72. Li, N.W.; Leng, Y.J.; Hickner, M.A.; Wang, C.Y. Highly Stable, Anion Conductive, Comb-Shaped Copolymers for Alkaline Fuel Cells. J. Am. Chem. Soc. 2013, 135, 10124-10133. [CrossRef] [PubMed]

73. Li, H.H.; Dong, J.H.; Cao, X.R.; Ren, X.R.; Hao, Z.; Yang, J.S. Diamine crossklinked anion exchange membranes based on poly(vinyl benzyl methylpyrrolidinium). Polymer 2021, 212, 123156. [CrossRef]

74. Nouri-Ahangarani, F.; Bahri-Laleh, N.; Nekoomanesh-Haghighi, M.; Karbalaie, M. Synthesis of highly isotactic poly 1-hexene using Fe-doped $\mathrm{Mg}(\mathrm{OEt})_{2} / \mathrm{TiCl}_{4} / \mathrm{ED}$ Ziegler-Natta catalytic system. Des. Monomers Polym. 2016, 19, 394-405. [CrossRef]

75. Zeng, L.; Zhao, T.S.; Li, Y.S. Synthesis and characterization of crosslinked poly (vinyl alcohol)/layered double hydroxide composite polymer membranes for alkaline direct ethanol cells. Int. J. Hydrogen Energy 2012, 37, 18425-18432. [CrossRef]

76. Choudhury, R.R.; Gohil, J.M.; Dutta, K. Poly(vinyl alcohol)-based membranes for fuel cell and water treatment applications: A review on recent advancements. Polym. Adv. Technol. 2021, 32, 4175-4203. [CrossRef]

77. Yang, J.M.; Wang, S.A. Preparation of graphene-based poly(vinyl alcohol)/chitosan nanocomposites membrane for alkaline solid electrolytes membrane. J. Membr. Sci. 2015, 477, 49-57. [CrossRef] 